Bangladesh J. Bot. 48(3): 609-617, 2019 (September)

\title{
VIRUS TITER AS A DISEASE RESISTANCE INDICATOR IN TOMATO
}

\author{
Sajid Ali, Ammara Fatima ${ }^{1}$, Sana Khalid ${ }^{2}$, Farah Saeed, Muhammad Shafiq, \\ Sohaib AfZaal*, Muhammad Saleem Haider, Wajeeha Tariq and Jahangir Khan \\ Institute of Agricultural Sciences, University of the Punjab, Lahore, Pakistan
}

Keywords: Tomato leaf curl virus, Vector-Bemisia-tabaci, Solanum lycopersicum

\begin{abstract}
Tomato leaf curl new Delhi virus, a geminivirus with a wide host range is a contagious pathogen of tomato, which also infects many other crops and weeds. Whitefly (Bemisia tabaci Gennadius), a polyphagous vector, is the agent responsible for its spread on a large scale. The pathogen is responsible for a major reduction in the yield of tomato. Ten commercial cultivars of tomato plant were selected to evaluate the effect of virus titer on crop yield. The yield potential along with other traits of these cultivars was assessed on the basis of symptom development, and virus DNA accumulation. The relationship between the virus titer, symptom severity, and agro-economic traits were established. The present results explain that the high level of virus accumulation in plant tissue results in the development of severe symptoms and leads to a major reduction in yield in case of susceptible cultivars, but this is not true for the cultivars showing intermediate resistance. The virus DNA remains low and approximately constant in resistant cultivars and has minimal effect on the yield and health of tomato.
\end{abstract}

\section{Introduction}

Tomato (Solanum lycopersicum L.) is universally treated as a vegetable, and is extensively grown as an annual plant. Tomato plants are herbaceous, annual to perennial, sexually (but occasionally asexually) propagated (Kimura and Sinha 2008). According to FAO survey in 2015, Pakistan produced 574052 tons of tomato from an area of 58196 ha $(9.86 \mathrm{t} / \mathrm{ha})$ during the year 2013. Tomato is susceptible to approximately 200 diseases (Aktar et al. 2016) caused by pests like fungi, bacteria and viruses. Many viruses also attack tomato crop and cause great economic losses. More than 20 viruses are known to infect tomato around the world and these losses reach up to 20$90 \%$. Some of the most devastating diseases of tomato are attributed to viruses belonging to the family Geminiviridae (Picó et al. 1996, Varma and Malathi 2003, Nowakowska et al. 2014).

Among all of the reported diseases, Tomato leaf curl new dehli virus (ToLCV), a geminivirus (Geminiviridae: subgroup - III) is the most devastating pathogen of cultivated tomato (Reddy et al. 2005, Borah and Dasgupta 2012) commonly occurring in Pakistan. It can affect the plant at any growth stage and is responsible for approximately $70 \%$ yield loss in tomato grown in February May (Tahir et al. 2012). If the infection occurs within the first four weeks of the transplantation, the yield losses may exceed 90 per cent.

ToLCV disease is characterized by the twisting, and curling of leaves followed by reduction in leaf size. The diseased plants look pale and stunted due to shortening of intermodal length with more lateral branches resulting in a bushy appearance. The whitefly Bemisia tabaci (Homoptera: Aleyrodidae) has been found to be the vector of the virus (Sastry and Zitter 2014). The vector life period is shortest during May-September being $11-14$ days as against 43 - 83 days during the cold months of December - February (Mann 2011). Injurious strains of B. tabaci have appeared

*Author for correspondence: <sohaib.afzaal@ hotmail.com>. ${ }^{1}$ Department of Environmental Science, Lahore College for Women University, Jail Road, Lahore. ${ }^{2}$ Department of Botany, Lahore College for Women University, Jail Road, Lahore. 
and spread from their home ranges to many other countries during the last 15 years. These strains have high fecundity and are more efficient as virus vectors than the indigenous population. In California, the newly appeared 'B' biotype of B. tabaci on the winter vegetable crop caused an estimated US \$200 million losses in yield and continues to cause a loss of the US \$130 million each year (Ramos et al., 2018). Tomato leaf curl disease is more serious in summer in the South and North part of Pakistan, but a high proportion of disease has also been observed in other seasons due to continuous and overlapping cultivation of tomato.

The host range of ToLCV and its vector B. tabaci is wide and can infect many annual and perennial plant species. They act as reservoirs throughout the year for both the vector and the disease (Muniyappa et al. 2000, Borah and Dasgupta 2012). The incidence of ToLCV is a major yield limiting factor because tomato plants of all ages are susceptible to the agent and show disease symptoms at 2 - 3 weeks after infection. Yield loss can be reduced by integrated disease management strategies like checking the vector population by using barriers, trap crops and application of systematic insecticides (Borah and Dasgupta 2012). However, coat protein mediated resistance by introducing the viral coat protein gene in crop plants is a consistent control against infection (Shin et al. 2002). Cloning and sequencing of the coat protein gene of the pathogen is a reliable method of knowing the existing variability among the virus isolates. The variability among the virus isolates and vector is the main reason for the breakdown of resistance (Pink et al. 1992, García-Arenal et al. 2001).

Though the disease has been known for a quite long period with a good amount of literature on various aspects of the disease, the long term strategies and additional creative approaches are needed now and then to reduce the losses currently sustained from ToLCV disease and information regarding the extent of the seasonal incidence of disease, epidemiology and type of vector / biotype of $B$. tabaci is scanty/meager in the tomato growing areas of Punjab. Therefore, the present study was planned and carried out to draw the attention of scientists to these objectives.

\section{Materials and Methods}

This experiment was conducted in the two consecutive years (2011 and 2012) at different locations of Punjab. Every set of experiment was replicated thrice following RCBD. Ten commercial varieties of tomato named as Tomato $F_{1}$ pound $\left(V_{1}\right)$, Fayoum $F_{1}$ hybrid $\left(V_{2}\right)$, Super special $\left(\mathrm{V}_{3}\right)$, Rio Grande $\left(\mathrm{V}_{4}\right)$, Tomato Fayoum $\left(\mathrm{V}_{5}\right)$, Tomato Remus $\left(\mathrm{V}_{6}\right)$, Tomato $1359\left(\mathrm{~V}_{7}\right)$, Tomato Romaking $\left(\mathrm{V}_{8}\right)$, Raja $\left(\mathrm{V}_{9}\right)$ and Money Maker $\left(\mathrm{V}_{10}\right)$ were used. Seeds were collected from the Federal Seed Certification and Registration Department (FSCRD), Lahore, Pakistan.

The experimental field was well prepared by different agronomic operations to ensure the complete removal of weeds. Manure and fertilizer were added in the field at the rate of 10 ton/ha cow dung, urea, TSP and MOP was applied @ 550, 450 and $250 \mathrm{~kg} / \mathrm{ha}$, respectively. Plants were seeded in March in earthen pots under the greenhouse and transplanted in May.

Whiteflies were reared in the cages on cotton plants. These were given 36 hrs acquisition access period to Tomato leaf curlnew dehli virus (ToLCNDV) infected S. lycopersicum. These were then released on the tomato nursery at the 3rd leaf stage to ensure $100 \%$ infection at 50 whiteflies/plant. Control plants (non-inoculated) were not exposed to whiteflies. The inoculated plants were kept in the insect proof greenhouse for 14 days, and then transplanted in the field. Plant to plant and row to row distance was maintained at 40 and $100 \mathrm{~cm}$, respectively. The plants were irrigated fortnightly with canal water. Insecticide sprays were applied to plants at 15 days interval throughout the experiment to control whiteflies (Verlaan et al. 2013). 
Plants were harvested twice during the single season. Only mature red fruits were collected in the 1st harvest. While, both mature red and immature green fruits were collected in 2nd harvest which was done 15 days after the 1st harvest. The parameters like number of fruits, yield plant, individual fruit weight, and yield/ha were also studied. Data were recorded fortnightly for each parameter and analyzed statistically by ANOVA following DMRT (Hruschka 2017) using computer based software Statistix ${ }^{\circledR} 10$.

Two hundred $\mu \mathrm{g}$ of leaf tissues were used to extract DNA by Cetyl tri-methyl ammonium bromide (CTAB) method (Doyle and Doyle 1990). Degenerative primers were used in PCR for preliminary identification of begomo virus infection (Rojas et al. 1993) as described previously (Fazeli et al. 2009). The presence of DNA-A genome components was detected using Tend (5' GGT ACC TAA GGA CCT GGG TTA TAG 3'), ToNDR (5' GGT ACC TGG ATA TGC TAG GTG TTA TAG 3') and CPF (5' ATG (C/A/T)(G/C)(G/C/A) AAG CG(A/T) $(\mathrm{C} / \mathrm{A}) \mathrm{C}(\mathrm{G} / \mathrm{C})$ (A/C)GA TAT 3'), CPR (5' TTA ATT (T/G/C)(C/G/A)(A/T/C) (A/T/G)A(C/T) $(\mathrm{A} / \mathrm{T} / \mathrm{C})(\mathrm{G} / \mathrm{C})$ $(\mathrm{C} / \mathrm{A} / \mathrm{T})(\mathrm{A} / \mathrm{G}) \mathrm{TC}$ ATA $\left.(\mathrm{G} / \mathrm{A}) \mathrm{AA}(\mathrm{A} / \mathrm{G}) \mathrm{TA} 3^{\prime}\right)$. Viral DNA in each band of the PCR product was quantified using Gel Analyzer software developed by Dr Istavan Lazar (Version 2010a). Standard values were provided to the software. The background level used as nil value for each measurement.

\section{Results and Discussion}

ToLCV usually infects the tomato crop resulting in severe yield reduction throughout the world/subcontinent. The loss observed in tomato grown field in February - May due to ToLCV attack was approximately 70\% (Borah and Dasgupta 2012). However, yield loss exceeds 90\%, when infection occurs within four weeks after transplanting in the field (Reddy et al. 2005). Here we report the results of ten selected commercial germplasms of tomato in which two cultivars $V_{6}$ and $\mathrm{V}_{8}$ exhibited high resistance against ToLCNDV were reported. Level of resistance was assessed in the field trial by comparing the yield potential of healthy and infected cultivars.

Cultivars were screened for symptom development during the period of summer as this season favors the disease development. The recorded average temperature of the experimental station was around $30^{\circ} \mathrm{C}$. There were fundamental differences in the onset and the degree of progression of symptoms in the selected cultivars (Sastry and Zitter 2014). In this study, cultivars $\mathrm{V}_{1}$ and $\mathrm{V}_{10}$ were the first to show vein clearing, reduction in leaf size, stunted growth, deformation of leaflets (Fig. 1A, E), inward and outward curling and puckering of leaflets (Fig. 1B, D, C) and were declared susceptible. The plants having a mild susceptibility $\left(\mathrm{V}_{2}, \mathrm{~V}_{5}\right.$ and $\left.\mathrm{V}_{7}\right)$ were next to produce curling and mosaic like symptoms on leaves (Fig. 1E). However, these varieties produced mild symptoms than those of susceptible varieties, whereas $V_{4}$ and $V_{9}$ varieties displayed varying levels of symptoms, mostly mild, while a few plants were asymptomatic overall and strong symptoms were very uncommon in these cultivars. Cultivar $V_{3}$ produced no yellowing and curling of leaves, but the inoculated plants showed stunted growth. In contrast $\mathrm{V}_{6}$ and $\mathrm{V}_{8}$ cultivars were absolutely symptomless and did not show stunting when compared with the healthy plants.

A major reduction in production cannot be based on a single parameter. The selected germplasms were evaluated for the degree of yield loss/ha caused by viral infection compared with healthy plants, as well as for the reduction in individual fruit weight, fruits/plant which ultimately caused yield loss (Varma and Malathi 2003). The experimental field conditions were favorable to pathogen for causing virulence i.e., high inoculation pressure and inoculation at early growth stages. Symptoms were assessed throughout the summer season, whenever they were exhibited by plants susceptible cultivars $V_{1}$ and $V_{10}$ produced extremely low yield as compared to inoculated resistant cultivars $\mathrm{V}_{6}$ and $\mathrm{V}_{8}$. These cultivars have the potential to produce growing and setting 
fruit even under extreme virus inoculation conditions. $\mathrm{V}_{6}$ and $\mathrm{V}_{8}$ cultivars exhibited the highest level of resistance to ToLCNDV, inoculated plants barely exhibited the symptoms and suffered only 22 to $30 \%$ yield losses when compared with the healthy plants. Minor damage was observed in fruit/plant and individual fruit weight (Table 1, Fig. 2).
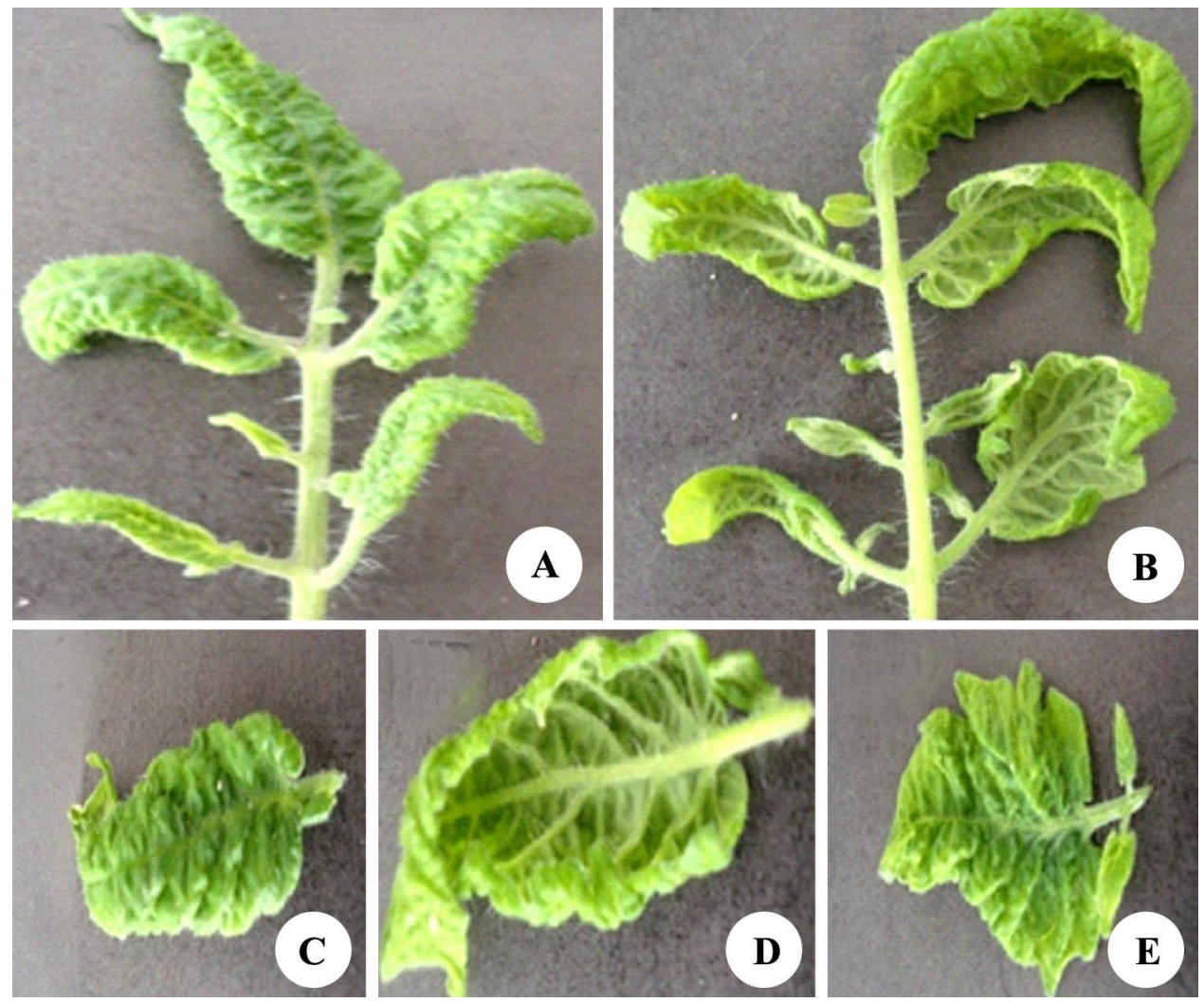

Fig. 1. Symptoms observed on tomato plants infected with ToLCNDV show stunted growth, deformed leaf lets, reduction of leaf size (A), inward and outward curling $(B, D)$, puckering of leafs $(C)$, mosaic and vein clearing $(\mathrm{E})$.

Susceptible plants rarely showed normal growth, however some plants bore fruits but the weight, number and yield of fruits/plant, and yield/ha were significantly lower as compared to healthy plants (Ji et al. 2007). In the present study, fruits produced on infected $\mathrm{V}_{5}$ cultivar were one third of that of the healthy plants both in yield/plant as well as in yield/ha (Table 1, Fig. 2). A comparison of inoculated plants with the control in terms of per plant and per hectare yield showed that cultivar $\mathrm{V}_{8}$ followed by $\mathrm{V}_{6}$ performed much better than other cultivars tested for resistance. The infected plants produced one third to one fourth yield per hectare as compared to healthy plants (Table 1, Fig. 2D).

Fargette el al. (1996) used serological study to categorize resistance level in geminiviruses (ToLCV) and found a relationship between the amount of virus and level of resistance in plant; they recommended that virus resistance can be evaluated by serological methods. Cultivar $\mathrm{V}_{8}$ exhibited the best level of resistance, measured in terms of fruit weight, fruits/plant, yield/plant 


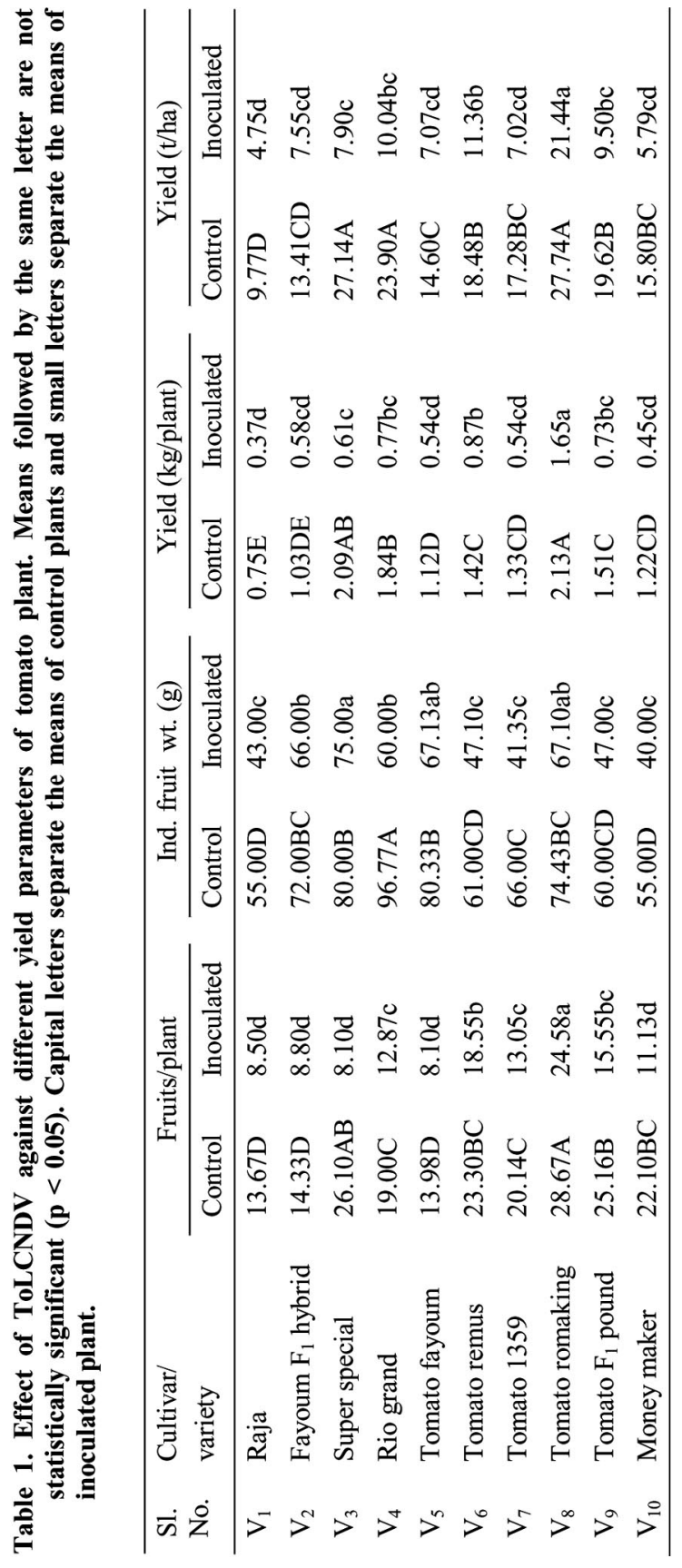


and yield/ha when compared with non-inoculated plants (Table 1, Fig. 2). All other cultivars suffered significant loss in studied parameters when compared with healthy plants. $\mathrm{V}_{2}$ and $\mathrm{V}_{3}$ showed non-significant difference in fruit weight, but a significant difference was observed in fruits/plant (Table 1, Fig. 2A, B). $V_{1}$ and $V_{10}$ cultivars were most affected in terms of the development of symptoms and reduction in the agro-economic traits as compared to healthy plants (Table 1, Fig. 2).
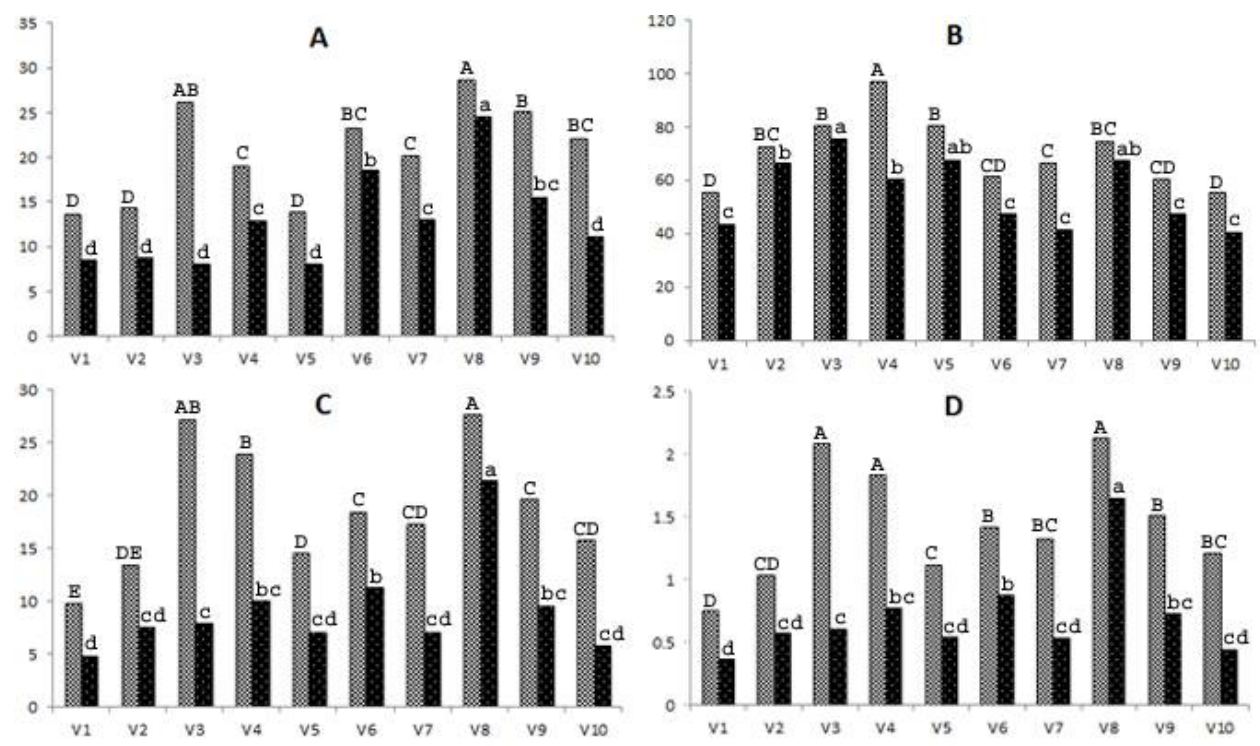

Fig. 2. Number of fruits/plant (A), individual fruit weight in gram (B), yield/plant in $\mathrm{km}(\mathrm{C})$ and yield/hectare in ton (D) was shown for Tomato $F_{1}$ pound $\left(V_{1}\right)$, Fayoum $F_{1}$ hybrid $\left(V_{2}\right)$, Super special $\left(V_{3}\right)$, Rio Grand $\left(\mathrm{V}_{4}\right)$, Tomato Fayoum $\left(\mathrm{V}_{5}\right)$, Tomato Remus $\left(\mathrm{V}_{6}\right)$, Tomato $1359\left(\mathrm{~V}_{7}\right)$, Tomato Romaking $\left(\mathrm{V}_{8}\right)$, Raja $\left(\mathrm{V}_{9}\right)$ and Money maker $\left(\mathrm{V}_{10}\right)$. Means followed by the same letter are not statistically significant $(\mathrm{p}<0.05)$. Capital letters separate the means of healthy plants and small letters separate the means of infected plants.

Under extreme infection, $\mathrm{V}_{6}$ and $\mathrm{V}_{8}$ cultivars were able to grow well and produced $80 \%\left(\mathrm{~V}_{6}\right)$, $86 \%\left(\mathrm{~V}_{8}\right)$ of number of fruits, $77\left(\mathrm{~V}_{6}\right), 90 \%\left(\mathrm{~V}_{8}\right)$ of individual fruit weight as compared with healthy control plants. Cultivar $\mathrm{V}_{6}$ exhibited a high level of resistance but lower than cultivar $\mathrm{V}_{8}$. Inoculated plants of cultivar $\mathrm{V}_{6}$ exhibited more damage in terms of individual fruit weight and fruits/plant which resulted in a reduction in yield. Inoculated plants of other cultivars showed variable losses in yield like 52\% $\left(\mathrm{V}_{1}\right), 44 \%\left(\mathrm{~V}_{2}\right), 71 \%\left(\mathrm{~V}_{3}\right), 58 \%\left(\mathrm{~V}_{4}\right), 52 \%\left(\mathrm{~V}_{5}\right), 59.4 \%\left(\mathrm{~V}_{7}\right), 52 \%$ $\left(\mathrm{V}_{9}\right)$ and $63.45\left(\mathrm{~V}_{10}\right)$.

Ji et al. (2007) used the viral DNA concentration present in infected plants tissue for screening of $S$. lycopersicon accessions against viral inoculums. In the present study it was also found that positive relationship in level of resistance, as a proof by comparative loss of yield and viral DNA concentration. This correlation was not valid in case of intermediate resistance, because viral DNA was less in cultivar $V_{3}$ and $V_{7}$ than in cultivar $V_{5}$ and $V_{9}$ plants, however, cultivar $V_{5}$ and $\mathrm{V}_{9}$ expressed more resistance than cultivar $\mathrm{V}_{3}$ and $\mathrm{V}_{7}$ in terms of fruits/plant, individual fruit weight, yield/plant and yield/ha (Tables 1, 2. Fig. 3). Moreover, the yield of cultivar $V_{2}, V_{5}, V_{7}$ and $\mathrm{V}_{10}$ were of the same level and differ non-significantly, but their viral DNA level was not same in any one of the cultivars suggesting that a reduction in virus titer is not only the factor that determine the level of resistance. 

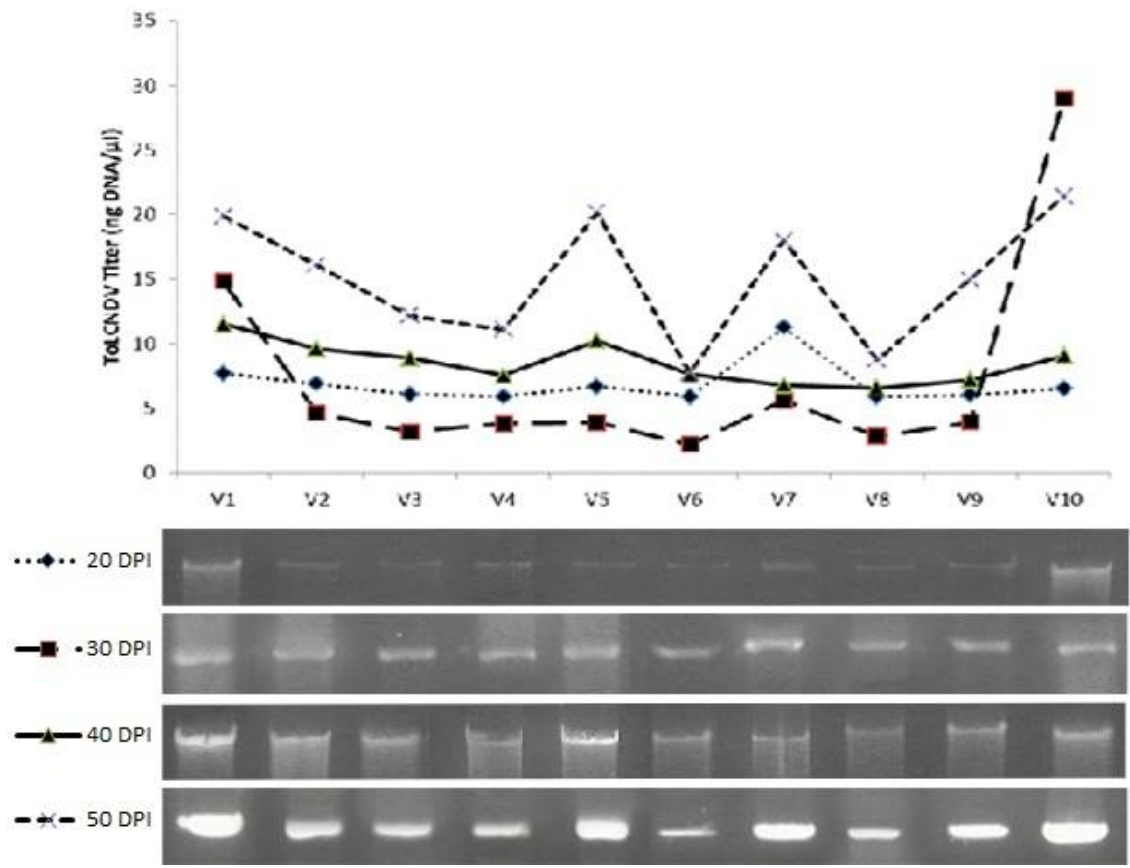

Fig. 3. ToLCNDV titer (ng DNA/ $\mu 1$ ) in the upper young leafs of different tomato cultivars at 20 days post inoculation (DPI), 30 DPI, 40 DPI and 50 DPI. Viral DNA was quantified by Gel Analyzer software as described in the text. Sampling was done at every $10^{\text {th }}$ day starting at 20 DPI. PCR analysis results was shown below the graph, genomic fragment $(\sim 700 \mathrm{bp})$ was amplified using begomovirus universal coat protein primers. Each amplified band at different time interval was shown under their respective cultivars, Tomato $F 1$ pound $\left(V_{1}\right)$, Fayoum $F_{1}$ hybrid $\left(V_{2}\right)$, Super special $\left(\mathrm{V}_{3}\right)$, RioGrand $\left(\mathrm{V}_{4}\right)$, Tomato Fayoum $\left(\mathrm{V}_{5}\right)$, Tomato Remus $\left(\mathrm{V}_{6}\right)$, Tomato $1359\left(\mathrm{~V}_{7}\right)$, Tomato omaking $\left(\mathrm{V}_{8}\right)$, Raja $\left(\mathrm{V}_{9}\right)$ and Money maker $\left(\mathrm{V}_{10}\right)$.

Table 2. ToLCNDVtiter (DNA ng/ $/ \mathrm{l}$ ) in the upper young leafs of different tomato cultivars at 20,30 , 40, and 50 DPI.

\begin{tabular}{llllll}
\hline Sl. & Cultivar/ & \multicolumn{4}{c}{ Virus titer (DNA ng/ $\mathrm{\mu l})$} \\
\cline { 3 - 6 } No. & cariety & 20 DPI & 30 DPI & 40 DPI & 50 DPI \\
\hline $\mathrm{V}_{1}$ & Raja & 7.716 & 14.832 & 11.51 & 19.88 \\
$\mathrm{~V}_{2}$ & Fayoum $\mathrm{F}_{1}$ hybrid & 6.892 & 4.606 & 9.6 & 16.074 \\
$\mathrm{~V}_{3}$ & Super special & 6.07 & 3.194 & 8.89 & 12.194 \\
$\mathrm{~V}_{4}$ & Rio grand & 5.896 & 3.796 & 7.554 & 11.104 \\
$\mathrm{~V}_{5}$ & Tomato fayoum & 6.688 & 3.88 & 10.254 & 20.15 \\
$\mathrm{~V}_{6}$ & Tomato remus & 5.912 & 2.214 & 7.612 & 7.732 \\
$\mathrm{~V}_{7}$ & Tomato 1359 & 11.26 & 5.584 & 6.816 & 17.986 \\
$\mathrm{~V}_{8}$ & Tomato romaking & 5.894 & 2.814 & 6.562 & 8.748 \\
$\mathrm{~V}_{9}$ & Tomato $\mathrm{F}_{1}$ pound & 6.026 & 3.928 & 7.21 & 14.97 \\
$\mathrm{~V}_{10}$ & Money maker & 6.522 & 28.98 & 9.076 & 21.444 \\
\hline
\end{tabular}

DPI: Days post inoculation. 
ToLCNDV DNA concentration in all cultivars was monitored at 20, 30, 40, 50 days after the inoculation. Virus titer was determined using Gel Analyzer software (Heras et al., 2015). Virus titer determined the level of resistance and yield loss in test varieties of tomato under same environmental conditions (Fazeli et al. 2009). Resistant cultivars $\mathrm{V}_{6}$ and $\mathrm{V}_{8}$ showed a low level of viral DNA in their tissue when compared to other susceptible cultivars (Table 2, Fig. 3). The same results were reported by Wege (2007) for resistant plants in which they observed the positive correlation between symptoms severity and level of virus accumulation. ToLCNDV DNA concentration level peaked two times during the growth period of plants at 30 Days post inoculation (DPI) and 50 DPI in cultivar $\mathrm{V}_{1}$ and $\mathrm{V}_{10}$ (Fig. 1). This is applicable only on susceptible varieties. The virus level in $\mathrm{V}_{6}$ and $\mathrm{V}_{8}$ was particularly constant and very low at $30 \mathrm{DPI}$. This explains the level of resistance in these two cultivars in terms of low virus titer and relatively small loss in yield.

The correlation between the viral DNA concentration and level of resistance held true for resistant varieties. The two best cultivars $\mathrm{V}_{6}$ and $\mathrm{V}_{8}$ had the lowest level of viral DNA in their tissues at different stages of growth. In the terms of yield performance, the correlation of improved resistance with low virus content was less applicable in case of moderate level of resistance. Cultivar $\mathrm{V}_{4}$ at 20 DPI and 40 DPI while cultivar $\mathrm{V}_{7}$ and $\mathrm{V}_{8}$ at 40 DPI, had less viral DNA titer than cultivar $\mathrm{V}_{6}$ and $\mathrm{V} 8$ and these cultivars exhibit lower level of resistance as expressed by yield parameters (Tables 1, 2. Figs 2, 3). The present study leads to the statement that viral DNA titer can serve as an indicator for the level of resistance but it cannot be concluded as a sole indicator.

\section{Acknowledgement}

Mr. Sohaib Afzaal is thankful to Ms. Sidra Anwar, Researcher at Plant Sciences Department, National University of Science and Technology (NUST), Islamabad, Pakistan for reviewing and editing this manuscript.

\section{References}

Borah BK and Dasgupta I 2012. Begomovirus research in India: A critical appraisal and the way ahead. J. Biosci. 37(4): 791-806.

Doyle J and Doyle J 1990. Isolation of plant DNA from fresh tissue. Focus. 12: 13-5.

Fargette D, Leslie M and Harrison BD 1996. Serological studies on the accumulation and localisation of three tomato leaf curl geminiviruses in resistant and susceptible Lycopersicon species and tomato cultivars. Annals App. Biol. 128: 317-328.

Fazeli R, Heydarnejad J, Massumi H, Shaabanian M and Varsani A 2009. Genetic diversity and distribution of tomato-infecting begomoviruses in Iran. Virus Genes. 38: 311-319.

García-Arenal F, Fraile A and Malpica JM 2001. Variability and genetic structure of plant virus populations. Annal Rev. Phytopathol. 39: 157-186.

Hameed S 1995. Leaf curl virus resistance in tomato and chilies. NARC Islamabad, South Asian Vegetable Research Network Virology Section (CDRI). pp. 315-319.

Heras J, Domínguez C, Mata E, Pascual V, Lozano C, Torres C and Zarazaga M 2015. GelJ-a tool for analyzing DNA fingerprint gel images. BMC Bioinforma. 16: 270.

Hruschka HW. 2017. Systematic Application of Duncan's Multiple Range Test to Biological Research Data (Classic Reprint). Fb\&c Limited, 11-Nov-2017.

Ji Y, Scott JW, Hanson P, Graham E and Maxwell DP 2007. Sources of resistance, inheritance, and location of genetic loci conferring resistance to members of the tomato-infecting begomoviruses. In: Tomato yellow leaf curl virus disease. 343-362. Springer, Dordrecht.

Kalloo G 1991. Disease resistance in tomatoes. Genetic improvement of tomato. Berlin Heidelberg New York Springer-Verlag., 99-108. 
Mann RS 2011. Bemisian tabaci interaction with cotton leaf curl virus. In: The Whitefly, Bemisia tabaci (Homoptera: Aleyrodidae) interaction with Geminivirus-Infected Host Plants. 69-88. Springer, Dordrecht.

Muniyappa V, Venkatesh, HM, Ramappa HK, Kulkarni RS, Zeidan M, Tarba CY, Ghanim M and Czosnek H 2000. Tomato leaf curl virus from Bangalore (ToLCV-Ban4): sequence comparison with Indian ToLCV isolates, detection in plants and insects, and vector relationships. Archiv. Virol. 145: 1583-1598.

Picó B, Díez MJ and Nuez F 1996. Viral diseases causing the greatest economic losses to the tomato crop. II. The Tomato yellow leaf curl virus-a review. Scient. Hort. 67: 151-196.

Pink DA, Lot H and Johnson R 1992. Novel pathotypes of lettuce mosaic virus-breakdown of a durable resistance?. Euphytica 63: 169-174.

Ramos RS, Kumar L, Shabani F and Picanço MC 2018. Mapping global risk levels of Bemisia tabaci in areas of suitability for open field tomato cultivation under current and future climates. PloS one 13(6): e0198925.

Reddy RC, Colvin J, Muniyappa V and Seal S 2005. Diversity and distribution of begomoviruses infecting tomato in India. Arch. Virol. 150(5): 845-67.

Rojas M.R, Gilbertson RL and Maxwell DP 1993. Use of degenerate primers in the polymerase chain reaction to detect whitefly-transmitted geminiviruses. Pl. dis. 77: 340-347.

Sastry KS, Zitter TA 2014. Management of virus and viroid diseases of crops in the tropics. In: Plant virus and viroid diseases in the tropics. 149-480. Springer Netherlands.

Shin R, Han JH, Lee GJ and Peak KH 2002. The potential use of a viral coat protein gene as a transgene screening marker and multiple virus resistance of pepper plants coexpressing coat proteins of Cucumber mosaic virus and Tomato mosaic virus. Transg. Res. 11: 215-219.

Varma A, Malathi VG 2003. Emerging geminivirus problems: A serious threat to crop production. Annals Appl. Biol. 142: 145-164.

Verlaan MG, Hutton SF, Ibrahem RM, Kormelink R, Visser RG, Scott JW, Edwards JD and Bai Y 2013. The Tomato yellow leaf curl virus resistance genes Ty-1 and Ty-3 are allelic and code for DFDGD-class RNA-dependent RNA polymerases. PLoS genetics. 9(3): e1003399.

Wege C 2007. Movement and localization of Tomato yellow leaf curl viruses in the infected plant. In Tomato yellow leaf curl virus disease. 185-206. Springer, Dordrecht. 